\title{
A biomaterials approach to influence stem cell fate in injectable cell-based therapies
}

\author{
Mahetab H. Amer, Felicity R. A. J. Rose, Kevin M. Shakesheff and Lisa J. White*
}

\begin{abstract}
Background: Numerous stem cell therapies use injection-based administration to deliver high-density cell preparations. However, cell retention rates as low as $1 \%$ have been observed within days of transplantation. This study investigated the effects of varying administration and formulation parameters of injection-based administration on cell dose recovery and differentiation fate choice of human mesenchymal stem cells.

Methods: The impact of ejection rate via clinically relevant Hamilton micro-syringes and biomaterial-assisted delivery was investigated. Cell viability, the percentage of cell dose delivered as viable cells, proliferation capacity as well as differentiation behaviour in bipotential media were assessed. Characterisation of the biomaterial-based cell carriers was also carried out.

Results: A significant improvement of in-vitro dose recovery in cells co-ejected with natural biomaterials was observed, with ejections within $2 \%(W / V)$ gelatin resulting in $87.5 \pm 14 \%$ of the cell dose being delivered as viable cells, compared to $32.2 \pm 19 \%$ of the dose ejected in the commonly used saline vehicle at $10 \mu \mathrm{l} / \mathrm{min}$. Improvement in cell recovery was not associated with the rheological properties of biomaterials utilised, as suggested by previous studies. The extent of osteogenic differentiation was shown to be substantially altered by choice of ejection rate and cell carrier, despite limited contact time with cells during ejection. Collagen type I and bone-derived extracellular matrix cell carriers yielded significant increases in mineralised matrix deposited at day 21 relative to PBS.

Conclusions: An enhanced understanding of how administration protocols and biomaterials influence cell recovery, differentiation capacity and choice of fate will facilitate the development of improved administration and formulation approaches to achieve higher efficacy in stem cell transplantation.
\end{abstract}

Keywords: Biomaterials, Cell therapy, Cell fate, Differentiation, Injectable, Mesenchymal stem cells

\section{Background}

To date, most clinical trials employing cell-based therapeutics have used injectable delivery of cellular suspensions in saline vehicles [1-3]. However, cell loss has been observed within the first minutes post injection [4], with less than $10 \%$ of injected cells retained at the site of interest $[2,5]$. Consequently, increasing the percentage of viable cells delivered and retained post injection is critical to the future success of cell transplantation procedures.

Mesenchymal stem cells (MSCs) have been the focus of numerous pre-clinical and clinical cell therapy studies [6]. Stem cell fate is regulated by biochemical and biophysical cues from the microenvironment $[7,8]$. As

\footnotetext{
* Correspondence: lisa.white@nottingham.ac.uk

Centre for Biomolecular Sciences, School of Pharmacy, University of Nottingham, Nottingham, UK
}

such, an intricate range of environmental effectors, experienced both during the delivery procedure and post transplantation, can impact cell function [9]. For example, cells experience various types of mechanical forces, including shear forces, during flow through a needle [10]. Although shear stress has been reported to directly influence the fate of undifferentiated stem cells $[11,12]$, the impact of mechanical forces experienced during clinically relevant injection procedures upon the differentiation potential of hMSCs has yet to be investigated.

Numerous studies have highlighted that the material surrounding a stem cell is vital in determining its fate [13-15]. Biomaterials can be used as cell delivery vehicles to provide physical support and protection for cells and stimulate host cell recruitment and differentiation 
[16]. Naturally derived biomaterials may exhibit inherent bioactivity that can facilitate tissue integration. Examples of naturally derived biomaterials include collagen, which has been shown to support cell growth in 3D cell culture studies and in vivo [17-21], and tissue-derived extracellular matrices (ECMs), harvested by decellularisation of mammalian tissues [22]. ECM materials retain the inherent bioactivity of the native matrix and modulate cell behaviour and promote constructive remodelling in vivo [23]. Other natural biomaterials, such as protein-based polymers, have found utility as cell carriers because these biomaterials may mimic characteristics of the natural ECM and influence the growth and fate of transplanted cells [24]. An example of naturally derived biomaterials is carboxymethyl cellulose (CMC), a biodegradable polysaccharide-based polymer with excellent biocompatibility $[25,26]$.

With the rising number of clinical trials exploring MSC-based cell therapies, an understanding of the factors that influence the functionality of cells post injection is critical. Despite the advantages of biomaterials as cell transplantation vehicles, saline-based cell carriers still continue to be the carrier of choice for many cell therapy clinical trials [1-3]. Since physical, chemical and biological factors have an impact on differentiation behaviour of cells [27], cues caused by variations in cell administration protocols can contribute to differentiation commitment decisions of MSCs. Our previous work provided evidence that ejection of cell suspensions at a low flow rate negatively impacted cell dose recovery, viability and function $[28,29]$. An enhanced understanding of how injectable biomaterials improve cell dose recovery and influence stem cell differentiation will facilitate the development of improved administration and formulation approaches to achieve higher efficacy and reduce variability in stem cell transplantation. The present study aimed to examine the influence of varying cell administration and formulation parameters on fate choice of hMSCs by assessing the impact of ejection upon the differentiation capacity of primary human MSCs using clinically relevant needles and by determining the potential value of user-friendly injectable biomaterials to improve delivery efficiency and to direct cell fate.

\section{Methods}

\section{Overall experimental design}

The general experimental design for this study is depicted schematically in Additional file 1: Figure S1. The first part of this study aimed to determine whether the initial cell seeding density influenced differentiation capacity. This was key to understanding whether any impact observed on differentiation capacity would be related to the number of cells being ejected at the slow flow rates employed [28] or to the effect of cell administration variables under investigation. The second part of the study assessed the impact of varying ejection rate on the differentiation capacity of ejected cells. Cell dose recovery and differentiation capacity of hMSCs ejected within various injectable biomaterial-based carriers were examined at low ejection rates. Differentiation to osteoblastic and adipogenic lineages was examined in bipotential differentiation 'mixed' media, with a formulation designed to induce both.

\section{Human mesenchymal stem cell culture}

Primary human bone marrow mesenchymal stem cells (hMSCs) were obtained from Lonza and cultured in mesenchymal stem cell growth medium (MSCGM) (\#PT3001; Lonza, Cologne, Germany) with $5 \% \mathrm{CO}_{2}$ in air at $37{ }^{\circ} \mathrm{C}$. Lot numbers of hMSC batches obtained were \#0000351482, \#0000411107 and \#0000422610, cultured as individual patient stocks. Cells used in this study were between the third and fifth passages. These cells were tested for the ability to differentiate into osteogenic, adipogenic and chondrogenic lineages, and for expression of surface markers recommended by the International Society for Cellular Therapy (ISCT) [30]. All routine passaging and differentiation procedures were performed according to Lonza's Poietics $^{\mathrm{st}} \mathrm{hMSC}$ protocols.

\section{Effects of cell seeding density on differentiation potential of hMSCs}

Cell seeding densities tested ranged from 1000 to 70,000 hMSCs per well in 12-well plates (Nunc, Thermo Fisher Scientific, UK), equivalent to $0.3 \times 10^{3}-18.4 \times 10^{3}$ cells/ $\mathrm{cm}^{2}$. Twenty-four hours after seeding, the medium was replaced with bipotential differentiation medium, formulated by combining adipogenic (\#PT-3004; Lonza) and osteogenic (\#PT-3002; Lonza) media in a 1:1 ratio. The culture was incubated for 21 days. The differentiation medium was changed every 3-4 days for the duration of the differentiation period. Nuclear-based cell counts were carried out using propidium iodide (PI) staining of the fixed cells in osteogenesis experiments and using Hoechst 33258 in adipogenesis studies.

\section{Preparation of hMSCs and ejection protocol}

After trypsinisation, cells were centrifuged and then reconstituted to a density of $1.4 \times 10^{6}$ cells $/ \mathrm{ml}$ in phosphate buffered saline (PBS) for cell ejection studies, and then were mixed 1:1 with either PBS or the biomaterialbased carrier under investigation (via gentle mixing) to a final density of $7 \times 10^{5}$ cells $/ \mathrm{ml}$. Density of cell suspensions used in this study was selected conservatively based on published clinical studies [31-33] as well as practical considerations. Aliquots $(100 \mu \mathrm{l})$ of this cell suspension were used for ejection experiments. Cells were directly pipetted into well plates (not ejected) to 
provide controls. For ejection, 100- $\mu$ l Hamilton GASTIGHT $^{\circ}$ syringes (model 1710RN) attached to 30G 20$\mathrm{mm}$ removable (RN) stainless steel needles were employed (Hamilton Bonaduz, Switzerland). All ejection studies were carried out at room temperature. Cell/carrier mixtures were set aside for 20 min before ejection, to represent the delay time between loading and injection in cell transplantation procedures [34]. Ejection rates employed in clinical trials have been variable, ranging from $5 \mu \mathrm{l} / \mathrm{min}$ [35] to $1000 \mu \mathrm{l} / \mathrm{min}$ for stroke $[36,37]$. Therefore, ejection rates employed in this study $(10-300 \mu \mathrm{l} / \mathrm{min})$ were selected to represent a range of clinically relevant ejection rates used previously in clinical trials. Cell suspensions were drawn up with a Harvard Infuse/Withdraw syringe pump (PHD 2000; Harvard Apparatus, MA, USA) at $300 \mu \mathrm{l} / \mathrm{min}$ through the needle before being ejected at the chosen flow rate into Eppendorf tubes. Ejected samples were then transferred into the appropriate well plates.

\section{Qualitative and quantitative assessment of differentiation capacity of ejected hMSCs}

Differentiation to osteoblastic and adipogenic lineages was examined in bipotential 'mixed' media (see 'Effects of cell seeding density'). Bipotential medium was added to the cells in 12-well plates at $24 \mathrm{~h}$ post seeding, and cells were alternated between adipogenic induction/ osteogenic induction media (1:1) and adipogenic maintenance/osteogenic media (1:1) every 3-4 days, according to the manufacturer's instructions, for 21 days. Uninduced controls were maintained in basal medium MSCGM (\#PT-3001; Lonza).

\section{Adipogenic differentiation}

After 21 days, cultures were rinsed with $70 \%(\mathrm{v} / \mathrm{v})$ isopropanol for $5 \mathrm{~min}$ and differentiation was assessed qualitatively by specific staining of lipid droplets with 0.5\% Oil Red O solution (Sigma-Aldrich, Poole, UK). Intracellular lipid accumulation was quantified using the AdipoRed $^{\text {Tw }}$ Adipogenesis Assay (Lonza) following the manufacturer's protocol. Briefly, cells were pre-washed with PBS and incubated with AdipoRed ${ }^{\mathrm{mm}}$ Reagent for $10 \mathrm{~min}$. Fluorescence was measured using a plate reader $\left(\lambda_{\text {exc }} / \lambda_{\text {em }} 485 / 572 \mathrm{~nm}\right)$.

\section{Osteogenic differentiation}

After 21 days of incubation, cells were fixed in 10\% (v/v) formalin. The presence of extracellular calcium deposits was qualitatively verified using Alizarin Red staining solution (Merck Millipore, UK) and von Kossa silver staining kit (Merck Millipore). For Alizarin Red staining, cells were treated with Alizarin Red $\mathrm{S}$ for $5 \mathrm{~min}$ at room temperature. After washing three times in deionised water, cells were observed microscopically. For von
Kossa staining, cells were incubated with silver nitrate solution under exposure to UV light for $20 \mathrm{~min}$. Wells were then washed with deionised water three times, and treated with sodium thiosulfate solution for $5 \mathrm{~min}$. Afterwards, wells were washed three times with deionised water. Mineralised nodules were visualised as black spots.

OsteoImage $^{\mathrm{Tn}}$ staining for quantitation of hydroxyapatite deposition In-vitro mineralisation was assessed by staining the hydroxyapatite portion of mineralised bone nodules using the OsteoImage ${ }^{\mathrm{Tn}}$ Mineralisation Assay kit (Lonza) according to the manufacturer's instructions. Briefly, cells were fixed in $10 \%(\mathrm{v} / \mathrm{v})$ formalin, rinsed twice using the wash buffer, stained with the staining solution provided (1:100 dilution in wash buffer) and incubated for $30 \mathrm{~min}$. Following incubation, cells were rinsed three times with wash buffer. This assay allows the assessment of in-vitro mineralisation both visually by fluorescent microscopy and quantitatively using a plate reader $\left(\lambda_{\text {exc }} / \lambda_{\text {em }} 492 / 520 \mathrm{~nm}\right)$.

Quantitative alkaline phosphatase staining For quantitative determination of alkaline phosphatase (ALP) activity, the Fluorometric Alkaline Phosphatase Assay Kit (\#ab83371; Abcam, UK) was used, as per the manufacturer's protocol. Cultured cells were lysed using three freeze-thaw cell lysis steps. Samples (media or cell lysate) were incubated with the non-fluorescent 4methylumbelliferyl phosphate disodium salt (MUP) as a substrate. The resultant fluorescence was measured using a plate reader. ALP activity was normalised to total DNA content, measured using the Quant-iT PicoGreen dsDNA Assay Kit (\#P11496; Invitrogen, UK).

Osteocalcin immunostaining hMSCs were rinsed with warm PBS and fixed with 3.7\% $(w / v)$ paraformaldehyde in PBS for $20 \mathrm{~min}$, followed by a wash with warm PBS for $5 \mathrm{~min}$. Cells were permeabilised using $0.1 \%(\mathrm{w} / \mathrm{v})$ Triton-X 100 in PBS (Sigma-Aldrich) for $30 \mathrm{~min}$. Nonspecific binding sites were blocked by incubation in $10 \%$ $(v / v)$ normal donkey serum (D9663; Sigma-Aldrich) and $1 \%$ bovine serum albumin (BSA) in PBS for $1 \mathrm{~h}$. Cells were then incubated with Mouse Anti-Human Osteocalcin Monoclonal Antibody (MAB1419; R\&D Systems) diluted in $1 \%(\mathrm{w} / \mathrm{v})$ BSA in PBS at $10 \mu \mathrm{g} / \mathrm{ml}$ for $3 \mathrm{~h}$ at room temperature. This was followed by two washes with PBS supplemented with $0.1 \%(\mathrm{w} / \mathrm{v})$ BSA (5 min each). The secondary antibody, a Donkey Anti-Mouse IgG-FITC antibody (NL007; R\&D Systems), diluted in $1 \%(\mathrm{w} / \mathrm{v}) \mathrm{BSA}$ in PBS (1:200) was added for $1 \mathrm{~h}$ in the dark, followed by two washes with PBS (5 min each). Samples were counterstained with DAPI NucBlue Fixed Cell ReadyProbes (ThermoFischer Scientific) for $5 \mathrm{~min}$, 
and then visualised using a Leica DM-IRB inverted microscope (Leica Microsystems Ltd., UK).

\section{Preparation of biomaterial-based carriers for ejection of hMSCs \\ Carboxymethyl cellulose}

CMC carriers were prepared using high-viscosity CMC (\#12M31P; Ashland Speciality Ingredients, Poole, UK) in tissue culture water at concentrations of $0.5 \%$ and $0.25 \%$ $(w / v)$. CMC carriers were sterilised by tyndallisation, carried out by heating the prepared solutions three times at $70{ }^{\circ} \mathrm{C}$ for $20 \mathrm{~min}$ each at $24-\mathrm{h}$ intervals.

\section{Type I collagen}

Commercially available high-concentration rat-tail collagen type I (\#354249, 10 mg/ml; BD Biosciences, Oxford, UK) was prepared at a concentration of $1.75 \mathrm{mg} / \mathrm{ml} \mathrm{fol-}$ lowing the manufacturer's instructions. Briefly, collagen was freshly prepared for experiments by combining rattail collagen type I with $10 \times$ PBS, ice-cold $1 \mathrm{~N}$ sodium hydroxide and sterile ice-cold deionised water to achieve a final collagen concentration of $1.75 \mathrm{mg} / \mathrm{ml}$. The solution was mixed and kept at $4{ }^{\circ} \mathrm{C}$.

\section{Bone extracellular matrix}

Decellularised and demineralised bone extracellular matrix (bECM) was obtained as described previously [38]. Briefly, liquid nitrogen was used to freeze bovine cancellous bone to facilitate fragmentation. Cancellous fragments were demineralised using $0.5 \mathrm{M} \mathrm{HCl}$ at room temperature for $24 \mathrm{~h}$. Following demineralisation, a solution of chloroform/methanol was used to remove lipids and then demineralised powder was subjected to $24 \mathrm{~h}$ of decellularisation in $0.05 \%$ Trypsin $/ 0.02 \%$ EDTA at $37{ }^{\circ} \mathrm{C}$. Powdered bone was combined with $1 \mathrm{mg} / \mathrm{ml}$ pepsin in $0.01 \mathrm{M} \mathrm{HCl}$ for a final concentration of $10 \mathrm{mg} / \mathrm{ml}$ and this suspension was stirred for $96 \mathrm{~h}$. Resultant bECM digests were aliquoted and stored at $-20{ }^{\circ} \mathrm{C}$ until required. Neutralisation of the required digest volume was carried out by addition of one-tenth of the digest volume of $\mathrm{NaOH}$ $(0.1 \mathrm{~N})$ and one-ninth of the digest volume of PBS (10x), and then diluting to the desired final bECM concentration with $1 \times$ PBS on ice. A concentration of $1.75 \mathrm{mg} / \mathrm{ml} \mathrm{bECM}$ was freshly prepared for ejection studies.

\section{Gelatin}

Commercially available $2 \%(\mathrm{w} / \mathrm{v})$ gelatin solution in water, derived from bovine skin (type B, \#G1393; SigmaAldrich), was used for biomaterial-based cell ejection studies.
Assessing cell recovery and proliferation using PrestoBlue ${ }^{\mathrm{Tm}}$ Since cell dose recovery results determined using PrestoBlue $^{\text {tw }}$ were shown previously to be comparable to the DNA-based Cyquant assay for determination of cell numbers ejected through Hamilton syringes [28]. PrestoBlue ${ }^{\mathrm{m}}$ (Invitrogen Life Sciences, Paisley, UK) was used to determine 24-h viability following ejection of cell suspensions $\left(7 \times 10^{5}\right.$ cells $\left./ \mathrm{ml}\right)$, as well as proliferation over several days. The PrestoBlue ${ }^{\mathrm{Tx}}$ :culture medium (1:9) mixture was added to each well, and incubated in the dark at $37^{\circ} \mathrm{C}$ for $1 \mathrm{~h}$. Triplicate 100- $\mu \mathrm{l}$ aliquots were measured for fluorescence on a Tecan Infinite M200 microplate reader (Tecan, Reading, UK) at $\lambda_{\text {exc }} / \lambda_{\text {em }} 560 / 590 \mathrm{~nm}$.

\section{Multiplexing quantitative differentiation assays with nuclear staining}

Multiplexing of cell-specific differentiation assays and nuclear staining allowed for normalisation to cell number. After differentiated cells were stained with the

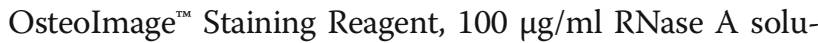
tion (AppliChem, Darmstadt, Germany) in Tris-EDTA buffer solution (Sigma-Aldrich) was added for $10 \mathrm{~min}$ at room temperature. Nuclear staining was carried out using $2 \mu \mathrm{g} / \mathrm{ml}$ PI (diluted in $\mathrm{H}_{2} \mathrm{O}$ from $1 \mathrm{mg} / \mathrm{ml}$; ThermoFisher Scientific, UK) for $5 \mathrm{~min}$. For quantitation, the mean fluorescence intensity of each well was determined using multiple readings of each well at $\lambda_{\mathrm{exc}} / \lambda_{\mathrm{em}} 490 / 530 \mathrm{~nm}$ for OsteoImage $^{\mathrm{Tm}}$ (>64 readings/well) and 535/617 nm for PI (100 readings/well). For quantification of adipogenesis, differentiated cells were stained with AdipoRed $^{\text {Tn }}$ Assay Reagent (Lonza). Nuclear staining in adipogenic analysis was carried out using $2 \mu \mathrm{g} / \mathrm{ml}$ Hoechst 33,258 (diluted in $\mathrm{H}_{2} \mathrm{O}$ from $1 \mathrm{mg} / \mathrm{ml}$; Sigma-Aldrich) for $15 \mathrm{~min}$. The mean fluorescence intensity of each well was determined using 100 readings per well.

\section{Rheological analysis of biomaterial-based carriers}

Rheological assessment was carried out with a Physica MCR301 rheometer (Anton Paar, UK) using rotational and oscillatory measurements. A 50-mm diameter cone plate (CP 50-1) was used, except for thixotropy recovery studies which were performed using a PP 25 parallel plate, with a $0.2-\mathrm{mm}$ measuring gap. All measurements were carried out at a controlled temperature of $25^{\circ} \mathrm{C}$. Samples were allowed to equilibrate for at least $2 \mathrm{~min}$ prior to analysis. A minimum of three independent measurements were obtained for each sample, and the average value was reported. Viscosity was determined using a constant shear rate of $1 \mathrm{~s}^{-1}$. The average value of all readings at 6-s intervals over a span of $120 \mathrm{~s}$ was taken as the viscosity measurement. Steady shear rheology was performed with a shear rate varying from 0.01 to $1000 \mathrm{~s}^{-1}$. Viscometric thixotropy testing was carried out by applying a highmagnitude strain $\left(10,000 \mathrm{~s}^{-1}\right)$ to break the biomaterial's 
structure, followed by a low-level strain $\left(1 \mathrm{~s}^{-1}\right)$ to observe the rate and extent of recovery of carrier bulk properties. Samples were also subjected to oscillatory strain sweeps from 0.1 to $1000 \%$ performed at $6 \mathrm{rad} / \mathrm{s}$ to assess the failure strain for these materials.

\section{Contact angle measurement}

Contact angles of the carriers with glass were measured using the sessile drop method. Soda-lime glass slides were used for measuring contact angles, which have similar wettability and surface tension in air to the borosilicate glass surfaces of syringes [39]. Contact angles were measured with a CAM 200 instrument (KSV Instruments, Finland) after 10-s spreading time. A drop of the material to be tested was formed on the end of a precision syringe and placed onto the glass slide. Ten images of the drop were taken at 1-s intervals. All measurements were made at $25{ }^{\circ} \mathrm{C}$. The contact angle was calculated for each image using a Young-Laplace curve fit using the CAM 200 image analysis software, and resulting right and left contact angles were averaged. A minimum of five repeat measurements were made for each material using separate glass slides.

\section{Statistical analysis}

Statistical analyses were performed using GraphPad Prism 6 software. Data sets were tested for normality and suitable tests of comparisons were subsequently chosen. All values were reported as mean value $\pm S D$, unless stated otherwise. Data were analysed by one-way or two-way analysis of variance (ANOVA) with Dunnett's post-hoc test, unless otherwise stated. $p \leq 0.05$ was considered significant.

\section{Results}

The first part of this study determined whether the initial cell seeding density influenced differentiation capacity. Previously, we showed that the ejection rate affected the cell dose delivered and that cell recovery was negatively impacted by low ejection flow rates $[28,29]$. Thus, it was critical to quantitatively assess the impact of the cell dose delivered upon the differentiation capacity. The second part of the study assessed the impact of varying ejection rate on the differentiation behaviour of ejected cells. Lastly, biomaterial-based formulations were selected as candidate biomimetic carriers to maximise hMSC recovery at low ejection rates and investigate the differentiation behaviour of ejected cells.

\section{Impact of initial cell seeding density on differentiation potential of hMSCs}

Hydroxyapatite deposition was used as a marker of osteogenic differentiation of hMSCs. Additional file 2: Figure S2A, B shows no significant difference in osteogenic differentiation between the various cell numbers seeded initially, as shown by amounts of hydroxyapatite deposited and normalised mineral deposition to cell number $(p<0.05)$. All cell densities exhibited similar final cell numbers at day 21, with lower initial cell seeding densities exhibiting a significantly higher fold change in cell number relative to day $0 \quad(p<0.05)$ when expressed as fold change in cell number relative to the number of cells initially seeded (Additional file 2: Figure $\mathrm{S} 2 \mathrm{C}$ ). There was no significant difference in the osteogenic differentiation of different cell seeding densities, as shown by fluorescence microscopy images of hydroxyapatite bone nodules (Additional file 2: Figure S2D).

In contrast to this, there was a clear correlation between initial seeding density and adipogenesis, as shown by AdipoRed ${ }^{\mathrm{TM}}$ staining and statistically significant differences in normalised fluorescence data relative to the full seeding density of $7 \times 10^{5}$ cells per well $(p<0.05$; Additional file 3: Figure S3A, B). The dependence of adipogenesis on initial cell seeding density is also shown in Additional file 3: Figure S3C, where fluorescence microscopy images demonstrate an increasing intensity of fluorescent staining of intracellular lipids with increasing initial cell seeding numbers.

The study therefore focused on osteogenesis for subsequent studies as a model of differentiation to investigate the impact of ejection rate on differentiation of ejected hMSCs, since mineralisation at day 21 was shown to be independent of the initial cell seeding density.

\section{Ejection rate influenced osteogenic differentiation of ejected hMSCs}

Directly plated control and ejected samples showed mixed populations of both adipocytes and osteoblasts. Samples ejected at $10 \mu \mathrm{l} / \mathrm{min}$ exhibited visibly less cells exhibiting the adipocyte morphology compared to other samples. In addition, brighter OsteoImage ${ }^{\mathrm{TM}}$ staining of hydroxyapatite (HA) was evident in the samples ejected at $10 \mu \mathrm{l} / \mathrm{min}$ relative to directly plated controls and other ejected samples (Fig. 1a). All ejected samples gave similar absolute fluorescence values when stained with OsteoImage $^{\mathrm{Tm}}$ (Fig. 1b); samples ejected at $10 \mu \mathrm{l} / \mathrm{min}$ exhibited lower cell numbers at day 21 relative to the control (Fig. 1c). However, samples ejected at $10 \mu \mathrm{l} / \mathrm{min}$ exhibited statistically significant higher normalised fluorescence values (Fig. 1d), compared to the directly plated control at 21 days $(p<0.05)$.

\section{Biomaterial-based delivery systems enhanced cell dose recovery and viability}

As retention in the delivery device and shear stress may result in a lower number of viable cells delivered, it was hypothesised that co-injecting cells with biomaterialbased carriers may improve recovery. Collagen type I, 

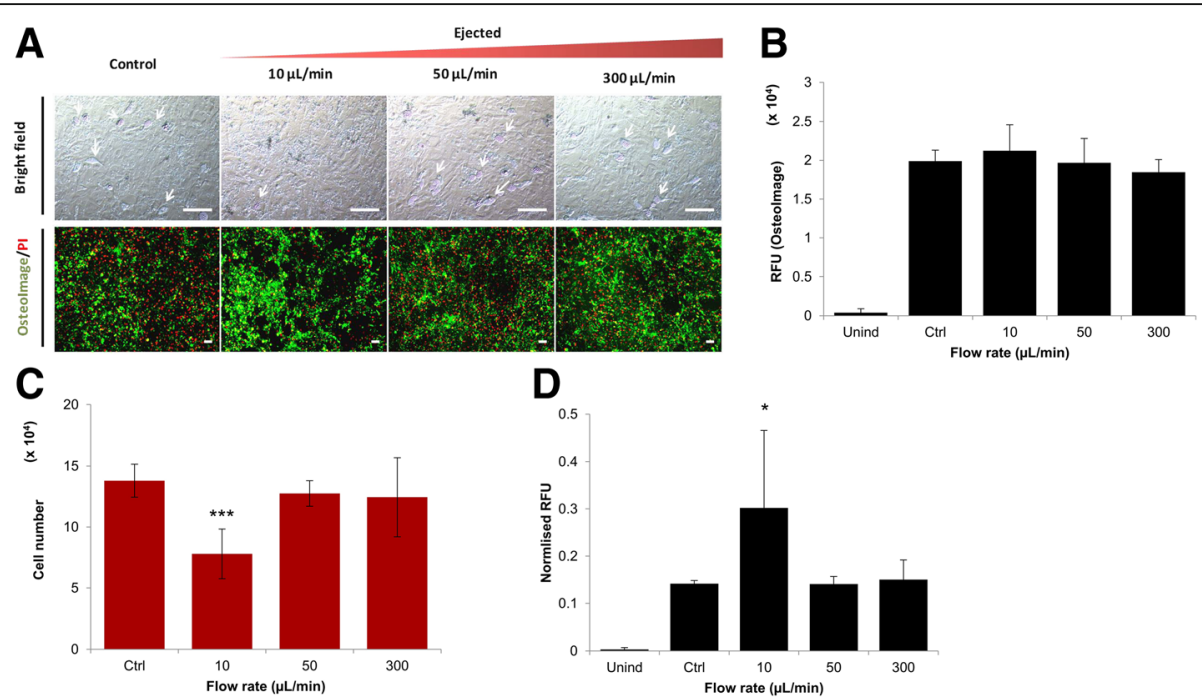

Fig. 1 Effect of ejection rate on osteogenic differentiation capacity of hMSCs ejected via 30G needles, cultured in bipotential osteogenic/ adipogenic media for 21 days. a Representative bright-field and fluorescence microscopic images showing ejected hMSCs after culturing in bipotential media. Cell nuclei stained red $(\mathrm{PI})$, mineralised areas stained green (Osteolmage ${ }^{\mathrm{TM}}$ ). Intracellular lipid accumulation indicated by arrows (scale bar $=100 \mu \mathrm{m}$ ). $\mathbf{b}$ Osteolmage ${ }^{\mathrm{TM}}$ fluorescence values for ejected hMSCs at day 21. Each bar represents mean fluorescence values \pm SD ( $n=9$ in three independent experiments and two donors). c Number of cells at day 21 quantitated using Pl staining of hMSCs from two donors (mean $\pm S D, n=6$ ). $\mathbf{d}$ Osteolmage ${ }^{\mathrm{TM}}$ fluorescence readings normalised to cell count, based on PI staining (mean $\pm S D, n=6$ ). Statistically significant difference from directly plated control using ANOVA and Dunnet's post-hoc test: ${ }^{*} p \leq 0.05,{ }^{* * *} p \leq 0.001$. PI propidium iodide, RFU relative fluorescence unit, Unind uninduced, Ctrl control

gelatin, bone decellularised ECM (bECM) and highviscosity CMC were selected to test this hypothesis. Incorporating cells in a protective viscous medium improved cell delivery (Fig. 2a). Cells suspended within $2 \%$ gelatin type $B$ exhibited the best recovery, with a significantly improved percentage of viable cells of $87.5 \pm$ $14.1 \%$ compared to $32.1 \pm 19.1 \%$ of the dose delivered when ejected with PBS. Relative to gelatin and CMC, delivery with collagen and bECM provided significantly lower percentages of viable cells, with $53.4 \pm 24.4 \%$ and $60.7 \pm 10.1 \%$ respectively delivered. To investigate the effect of using a lower concentration of the same material, two concentrations of CMC $(0.5 \%$ and $0.25 \%(w / v))$ were compared (Fig. 2b). The lower concentration $(0.25 \%$ $(\mathrm{w} / \mathrm{v}))$ of $\mathrm{CMC}$ resulted in a significantly lower percentage of the dose being delivered as viable cells $(p=0.05)$.

Live/Dead staining revealed a high proportion of viable cells among all cell carriers investigated (Fig. 2c). However, a visibly lower number of cells appeared in ejected samples suspended in PBS compared with other carriers. Bright-field images of the ejected samples $24 \mathrm{~h}$ post ejection (Fig. 2d) displayed an obvious presence of fibril-like structures in samples ejected within collagen and bECM; cells ejected within other carriers did not display fibrillogenesis. These fibrils were not stained by calcein (Fig. 2c). The proliferative ability of ejected hMSCs was not significantly affected by choice of cell carrier, with similar fold changes in cell numbers observed at day 10 relative to the control (Fig. 2e).

\section{Characterisation of biomaterial-based carriers}

The rheological properties and surface tension of the carriers were characterised to elucidate the effects of material properties upon cell behaviour. Gelatin displayed the lowest viscosity $(0.01 \pm 0.0007$ Pa.s $)$ and collagen the highest $(0.66 \pm 0.11$ Pa.s) (Fig. 3a). The steady shear rheological properties of the carriers are presented in Fig. 3b. bECM, gelatin and collagen showed more significant shear-thinning profiles $\left(\Delta \eta \sim 10^{4} \mathrm{~Pa} . \mathrm{s}\right)$ than both concentrations of CMC $\left(\Delta \eta \sim 10^{2}\right.$ Pa.s). Collagen had a viscosity of around 150 Pa.s at a shear rate of $0.01 \mathrm{~s}^{-1}$, shearing down to 0.001 Pa.s at $1000 \mathrm{~s}^{-1}$. Gelatin exhibited a viscosity of around 1 Pa.s at $0.01 \mathrm{~s}^{-1}$, shearing down to 0.002 Pa.s at a shear rate of $1000 \mathrm{~s}^{-1}$ and not crossing over the profiles of both CMC concentrations.

A viscometric three-step thixotropy test was carried out to investigate recovery of material properties (Fig. 3c). $\mathrm{CMC}$ and collagen showed fast and complete recovery within seconds. Gelatin recovered its viscosity within a few seconds to almost $90 \%$ of its initial value, but started breaking down $70 \mathrm{~s}$ following strain removal. bECM showed a more gradual recovery to almost $65 \%$ of its original properties at $180 \mathrm{~s}$ following strain removal. Due to their shear-thinning and self-healing properties, all carriers investigated were shown to be injectable through a clinically relevant 30G needle (Fig. 3d).

All cell carriers employed in this study, except CMC, showed higher storage moduli than loss moduli, with curves being parallel and almost linear, which confirmed 

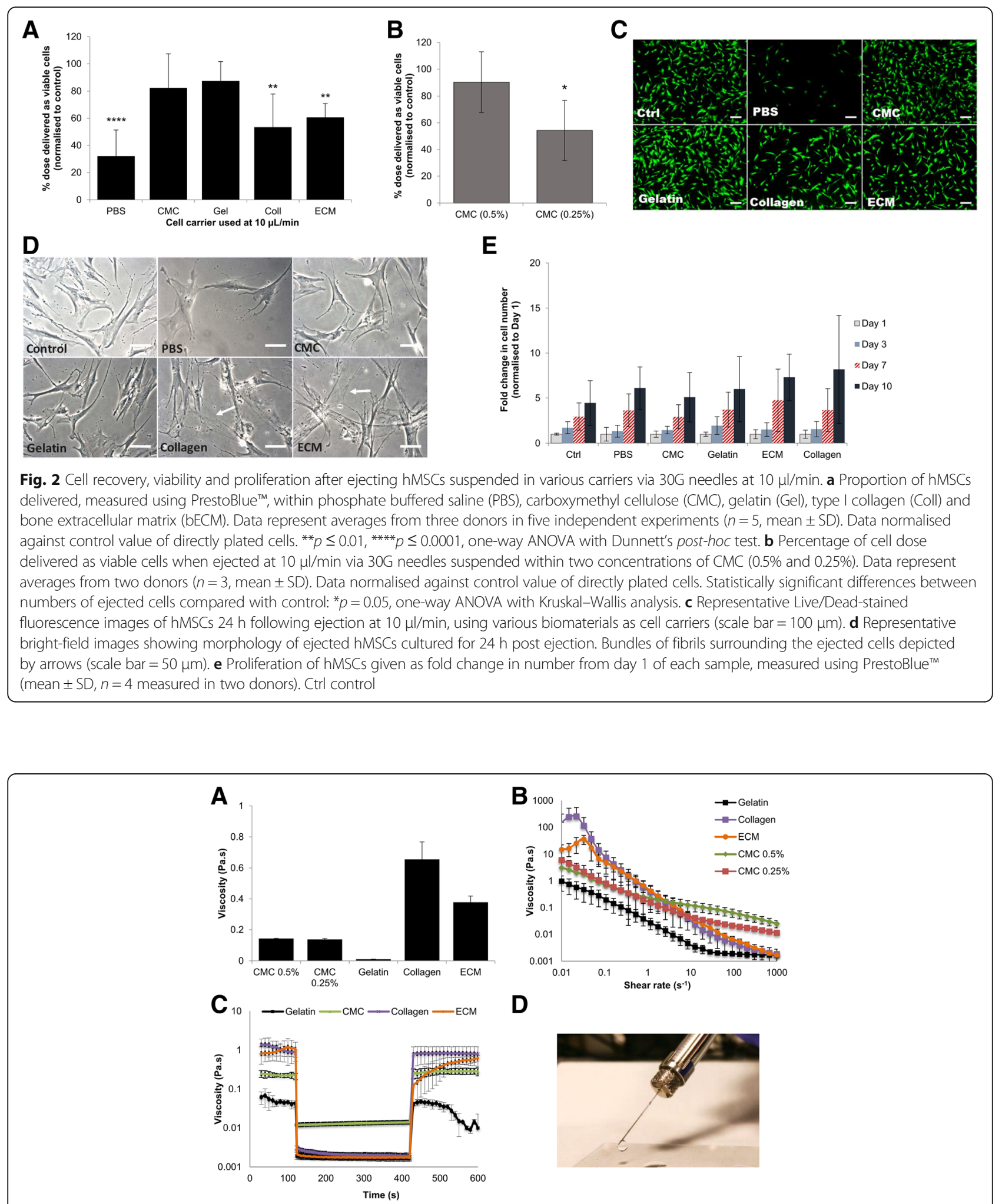

D

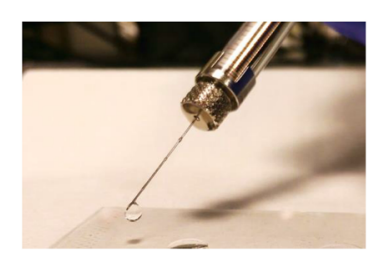

Fig. 3 Rheological characterisation of biomaterial-based cell carriers employed in this study. a Viscosities of carriers determined at $25^{\circ} \mathrm{C}$ with a constant shear rate of $1 \mathrm{~s}^{-1}$ (mean $\pm \mathrm{SD}, n=3$ ). $\mathbf{b}$ Shear thinning properties of different carriers employed shown by steady shear rheological measurements. c Viscometric three-step thixotropy test to display structure recovery of the hydrogel immediately after disruption due to a highmagnitude shear-rate strain $\left(10,000 \mathrm{~s}^{-1}\right)$, followed by a low-magnitude strain $\left(1 \mathrm{~s}^{-1}\right)$ to monitor recovery of bulk properties. $\mathbf{d}$ CMC $0.5 \%$ ejected through a $30 \mathrm{G}$ needle, representative of injectability of biomaterials investigated. CMC carboxymethyl cellulose, ECM extracellular matrix 
their hydrogel nature. However, CMC displayed a higher $G^{\prime \prime}$ than $G^{\prime}$, and should therefore be classified as a viscous carrier or viscosity modifying excipient. All carriers displayed broad linear viscoelastic regions (Additional file 4: Figure S4). Collagen and bECM exhibited failure of the gel structure at high strains of around $65 \%$ and demonstrated strain stiffening behaviour.

All biomaterials exhibited water contact angles ranging from $18^{\circ}$ to $35^{\circ}$ (Fig. 4a). PBS, collagen and bECM were the most hydrophilic; PBS had the lowest contact angle of $18.6 \pm 3.0^{\circ}$, while collagen was less hydrophilic with a contact angle of $24.0 \pm 2.7^{\circ}$. Gelatin was the least hydrophilic among the biomaterials investigated, with a contact angle of $34.3 \pm 5.0^{\circ}$ (Fig. 4b). The more dilute concentration $(0.25 \%)$ of CMC exhibited a lower contact angle of $29.0 \pm 5.8^{\circ}$, compared to $33.4 \pm 4.1^{\circ}$ for the higher concentration of $0.5 \%$ (Fig. 4c).

\section{Impact of biomaterial-based cell carriers upon differentiation capacity of hMSCs}

All directly plated control and ejected hMSCs underwent osteogenic differentiation after 21 days of culture in bipotential medium (Fig. 5). All samples exhibited a mixed population of cells displaying typical adipocyte morphology as well as mineralised bone nodules. PBSejected samples consistently displayed visibly lower numbers of cells exhibiting adipocyte morphology, in addition to some cells displaying a fibroblast-like morphology typical of undifferentiated MSCs. Whilst fluorescence images indicated that all control and ejected samples exhibited mineralisation, a notably higher extent of calcium and hydroxyapatite deposition was observed in samples ejected within collagen and bECM compared to the control and other carriers. Quantitative assessments of hydroxyapatite deposition (Fig. 6a) confirmed that cells co-ejected within collagen, bECM and gelatin led to significantly enhanced mineralised content relative to samples ejected within PBS. However, all samples exhibited no significant difference in normalised fluorescence values (Fig. 6b).

To determine whether ejection forces and biomaterialbased delivery had a synergistic effect upon mineralisation, hydroxyapatite deposition was compared in cells suspended within collagen and bECM, either directly plated in 12-well plates (referred to as 'plated') or ejected at $10 \mu \mathrm{l} / \mathrm{min}$ ('ejected'). Samples were directly plated at $60 \%$ of the initially ejected cell number within each carrier material to account for the loss of cells during ejection and to preclude any potential influence of initial seeding density (Fig. 2a). As shown in Fig. 6c, d, there was no significant difference in hydroxyapatite deposition between the directly plated and ejected cells within collagen and bECM at day 21, in terms of both absolute and normalised values.

To determine whether ALP was released into the media as a result of shear stress exposure, culture media were assayed following induction of differentiation. At day 2, media ALP activity was generally higher in ejected hMSCs compared to directly plated samples. Ejection within PBS and bECM increased released ALP activity compared with directly plated hMSCs (Fig. 6e, $p<0.05$ ). To determine whether ejection forces and biomaterialbased carriers had a synergistic effect upon released ALP, media ALP levels in plated versus ejected cells,

A

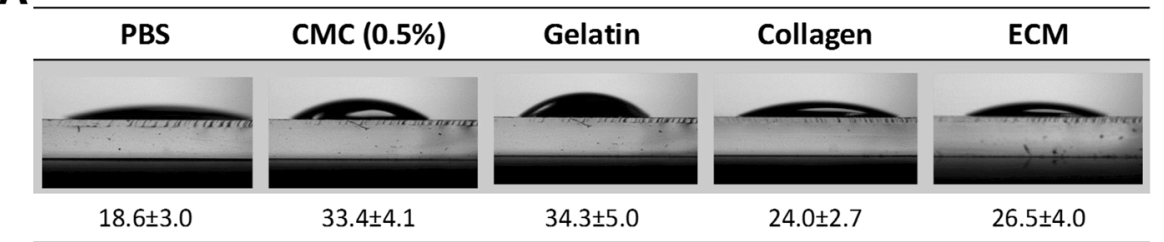

B

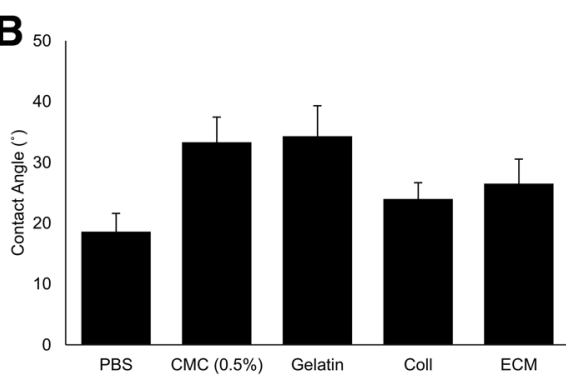

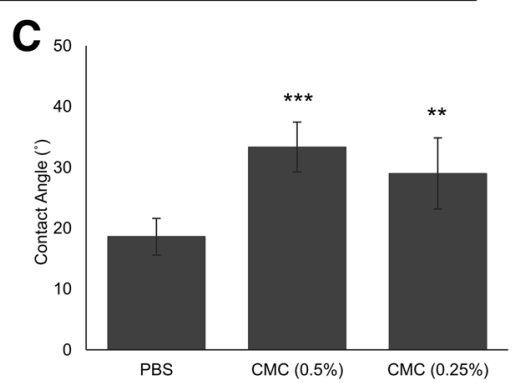

Fig. 4 Measurement of contact angles of biomaterial-based cell carriers on a glass surface. a Contact angle images of various biomaterials employed on soda-lime glass slides measured at room temperature. $\mathbf{b}, \mathbf{c}$ Measurement of contact angles of various carriers on a soda-lime glass surface. Each bar represents mean $\pm \mathrm{SD}(n=5) .{ }^{* *} p<0.01,{ }^{* * *} p<0.001$, relative to PBS. PBS phosphate buffer saline, CMC carboxymethyl cellulose, Coll collagen, ECM extracellular matrix 


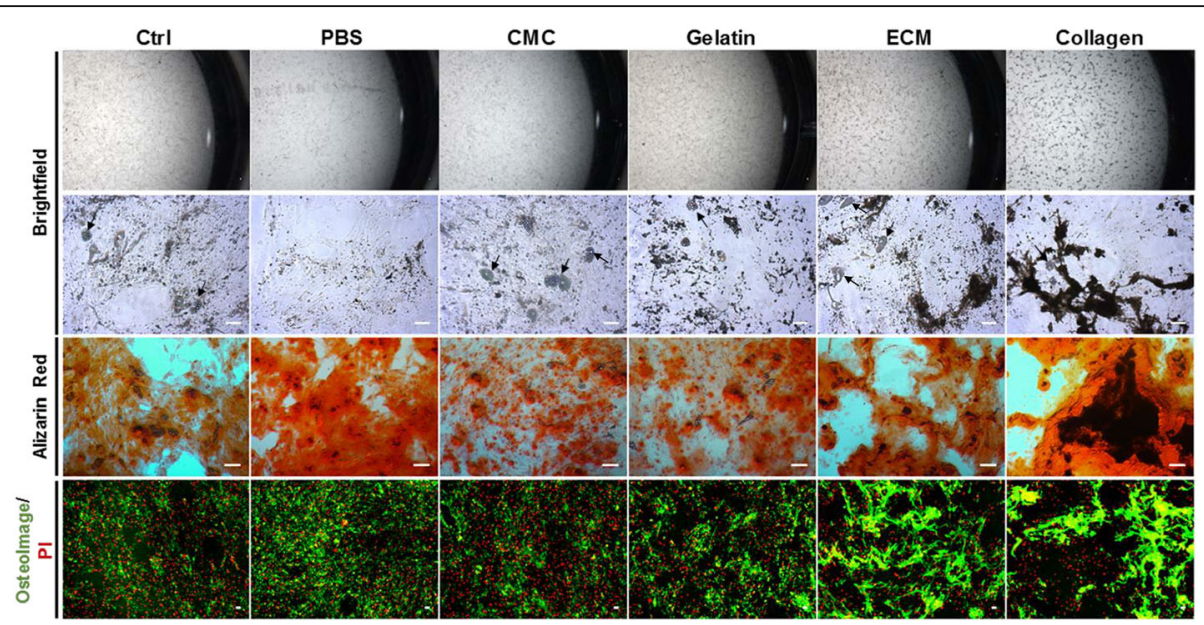

Fig. 5 Representative bright-field and fluorescence microscopy images displaying qualitative assessment of osteogenic differentiation capacity of hMSCs post ejection, after culturing in bipotential 'mixed' media for 21 days. To assess the degree and distribution of mineralisation of the ECM, the last stage of osteogenesis, samples were observed using dissection and bright-field microscopy (10x), in addition to staining with Alizarin Red $\mathrm{S}(10 \mathrm{x})$ and Osteolmage ${ }^{\mathrm{TM}} / \mathrm{PI}(5 \mathrm{X})$. Cells exhibiting typical adipocyte morphology depicted in bright-field microscopy images using arrows (scale bars $=50 \mu \mathrm{m}$ ). Red represents calcium deposition stained using Alizarin Red, and green depicts hydroxyapatite nodules stained using Osteolmage $\mathrm{e}^{\mathrm{TM}}$. Ctrl control, PBS phosphate buffer saline, CMC carboxymethyl cellulose, ECM extracellular matrix, PI propidium iodide

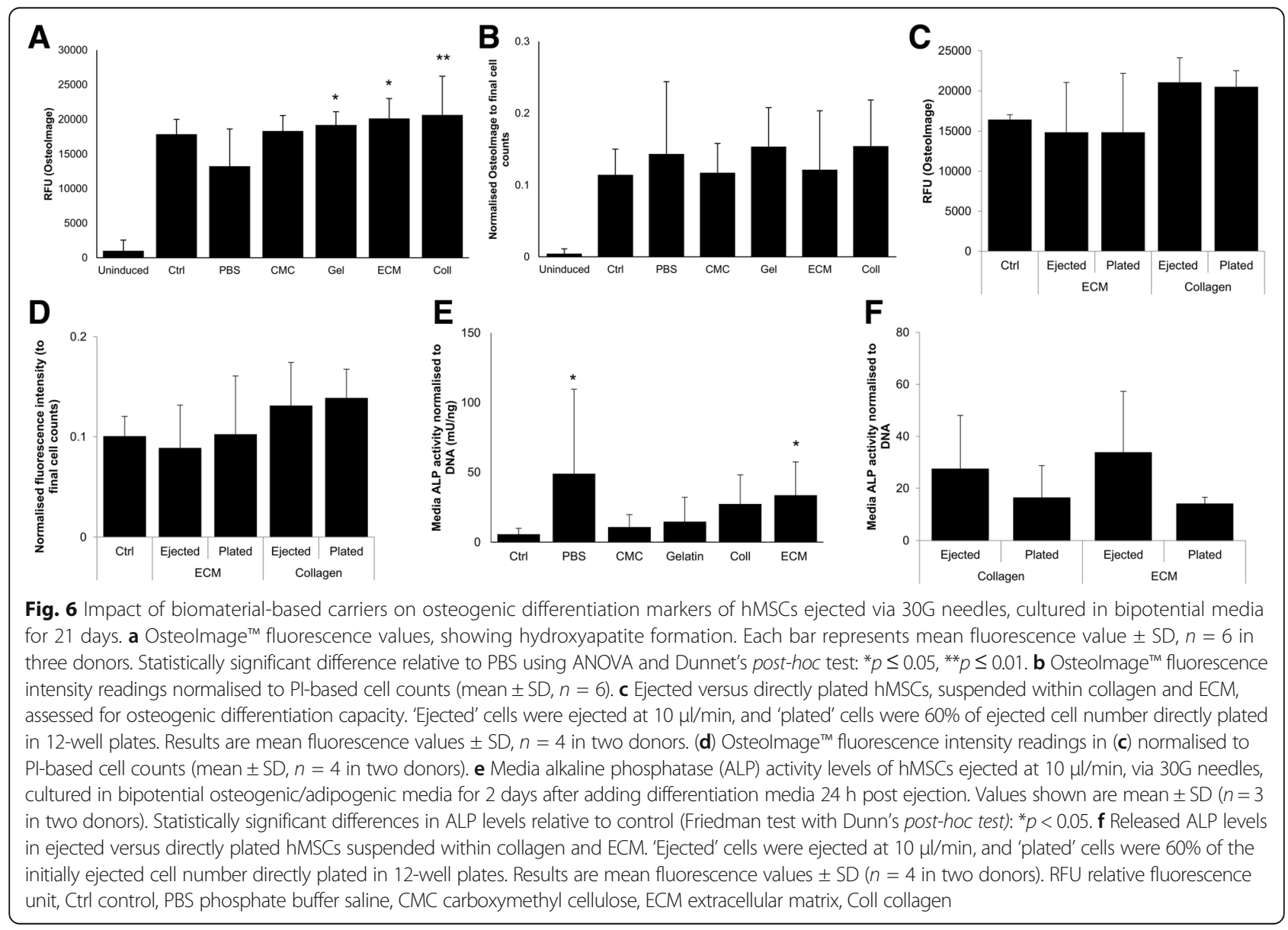


suspended within collagen or bECM, were compared. Figure $6 \mathrm{f}$ shows increased media ALP levels in ejected samples relative to plated ones within collagen and bECM.

Although total cellular ALP activity was significantly lower for hMSCs ejected within PBS than for control samples at day 2 (Additional file 5: Figure S5A), normalised levels of ALP production were similar for all samples tested at this time point (Additional file 5: Figure S5B). Expression of normalised cellular ALP generally peaked earlier (day 4) for directly plated samples compared to ejected samples (day 7). To explore whether shear forces contributed to ALP expression pattern, directly plated and ejected hMSCs within bECM and collagen carriers were compared. The same pattern of normalised ALP levels peaking earlier (at day 4) in directly plated samples relative to ejected samples was observed (Additional file 5: Figure S5C), and no significant differences in DNA content (Additional file 5: Figure S5D). After 21 days, immunostaining for osteocalcin (OCN) showed a robust expression of this late osteogenic marker across all samples after 21 days of culture (Additional file 5: Figure S5E).

\section{Discussion}

Since previous work demonstrated that cell ejections at slower flow rates resulted in lower percentages of the cell dose being delivered [28, 29], experiments were carried out first to investigate the dependence of differentiation capacity on initial cell number using bipotential media. In typical monopotential differentiation media, two different variables may act to direct hMSCs down a certain differentiation pathway: biochemical-based induction or effects of exposure to mechanical forces of ejection. Deducing the impact of physical cues on cell differentiation fate is difficult to explore within the chemically defined environments of monopotential differentiation media. By using 'mixed' media, a bipotential setting was provided whereby the appropriate chemical differentiation cues required for both osteogenesis and adipogenesis were available. This allowed us to study the impact of physical cues, such as mechanical forces or cell carrier, on cell lineage fate independent of chemical dosing variables.

\section{Impact of cell seeding density on differentiation capacity of hMSCs}

No statistically significant differences were detected in hydroxyapatite deposition at the initial seeding densities under investigation. Thus, we postulated that the different initial cell seeding numbers resulting from the various ejection rates tested had negligible effects on mineralisation at day 21 , even at the lowest flow rate under investigation ( $35 \%$ of cell dose is delivered at $10 \mu \mathrm{l} / \mathrm{min}$ [28]). These results are consistent with findings from studies carried out on various scaffolds, which demonstrated that higher seeding densities do not necessarily produce enhanced proliferation and differentiation [40, 41]. Holy et al. [42] investigated the effect of initial seeding density upon rat bone marrow-derived cell differentiation on PLGA scaffolds and showed that final mineralised tissue formation was independent of initial seeding density.

When cell numbers at day 21 were expressed as fold change in cell number to initial cell seeding number, it was found that lower seeding densities corresponded to the highest proliferation, which agrees with previous studies by McBeath et al. [43]. In contrast to the effect on the osteogenesis marker quantified, the adipogenic differentiation capacity was influenced by cell seeding number. This result is in line with previous findings [43, 44]. As mineralisation at day 21 was shown to be independent of initial cell seeding density, osteogenesis was selected as the model for this study. Osteogenesis is a robust, wellestablished in-vitro cellular model of differentiation in hMSCs with well-defined assays and measurable outputs [45].

\section{Ejection rate influenced osteogenic differentiation capacity of ejected hMSCs}

Since we established that the different cell numbers ejected at different rates did not influence total mineralisation levels nor normalised mineralisation-to-cell-number values at day 21 , we moved on to investigate the impact of ejection rate on the osteogenic differentiation capacity of ejected hMSCs.

Exposure of MSCs to shear stress, whether controlled (fluid flow) or uncontrolled (flow perfusion), has been reported to result in enhanced osteogenic matrix production and maturation [46-48]. Previous work has qualitatively demonstrated that MSCs ejected at $10 \mu \mathrm{l} / \mathrm{min}$ resulted in considerably lower osteogenic differentiation capacity [28], but no further investigation was carried out. Normalised mineralisation values of cells growing in the bipotential differentiation environment showed a significantly higher level of mineral deposition per cell at the lowest flow rate $(10 \mu \mathrm{l} / \mathrm{min})$ relative to control (Fig. 1b). This suggests that hMSCs ejected at this rate either preferentially underwent osteogenic differentiation relative to the other samples, started differentiating earlier or had enhanced osteogenic efficiency per cell. These differentiation trends confirmed that prolonged exposure to the mechanical forces generated at $10 \mu \mathrm{l} / \mathrm{min}$, rather than cell density and associated cell-cell interactions, influenced the differentiation fate of ejected cells. 


\section{Biomaterial-assisted delivery}

The development and evaluation of convenient, costeffective and efficient cell delivery systems will aid the translation of cell-based therapies to the clinic. This study explored whether the use of naturally derived biomaterials will influence cellular differentiation and potentially stimulate endogenous regeneration, acting as instructive cell delivery platforms. This study investigated the effects of using various natural biomaterialbased cell carriers for ejection of hMSCs on cell dose recovery, commitment and differentiation capacity in a clinically relevant syringe/needle ejection scenario. The choice of biomaterials reflects our aim to achieve simple, reproducible and clinically relevant delivery of hMSCs to facilitate low-dosage cell therapies.

Since there are unavoidable delays in any clinical cell delivery procedure, cell carriers may provide physical and chemical cues within this time that would inevitably direct cell functionality outcomes, such as proliferation and differentiation. Within biomaterials, cues may include material composition as well as external physical cues resulting from the exposure of cells to mechanical forces associated with injection procedures. Materials utilised in this study were chosen to be readily available, customisable, user-friendly and easily injectable through clinically relevant needles. Since ECM, composed mainly of proteoglycans, glycosaminoglycans and fibrous proteins (e.g. collagen), provides key biochemical and biomechanical cues required for tissue differentiation and homeostasis [49], materials were also selected based on major components of the ECM. Protein-based polymers have the advantage of mimicking characteristics of the natural ECM, and thereby the potential to impact the growth and organisation of transplanted cells [24]. Collagen type I, for example, has been widely applied as scaffolds for cell delivery, including animal models of brain injury, with good biocompatibility [50, 51]. Similarly, gelatin is a hydrolysed form of collagen [52] with biomechanical similarity to the ECM [53]. The supplementation of algal cultures with $\mathrm{CMC}$, as a modifier of interfacial properties, has been reported to protect algal cells against hydrodynamic stress [54].

Results revealed that utilising injectable hydrogels and viscosity modifying excipients for cellular delivery demonstrated positive effects on cell recovery (Fig. 2). A significant loss of cells at $10 \mu \mathrm{l} / \mathrm{min}$ was observed in unprotected (PBS) samples at $24 \mathrm{~h}$ post ejection. Gelatin (protein-based) and CMC (polysaccharide-based) cell carriers displayed the highest percentage of viable cells delivered, with no significant difference to directly plated samples. In comparison, collagen and bECM carriers (both protein based) resulted in lower cell recovery, yet were significantly better than ejecting within PBS. An improvement in cell viability post ejection was obtained previously by Aguado et al. [10] using alginate gels via a 28G needle, which had been suggested to be due to plug flow, whereby the hydrogel adjacent to the walls undergoes shear thinning and forms a fluid layer which acts as a lubricant [55]. This lubricating fluid layer may be one explanation for the higher percentages of the cell doses delivered in this study through keeping the cells in the central plug zone away from the walls. The significant improvement in cell dose recovery demonstrated herein, in clinically relevant narrow-bore needles at low ejection rates used in clinical trials $[35,56]$, may be vital to cells that display biological changes after exposure to mechanical forces.

Live/Dead staining confirmed that all tested carriers conserved a high degree of viability of ejected cells. Microscopy revealed a dilute meshwork of what appears to be collagen fibrils dispersed between cells in samples ejected within collagen and bECM, since they were not stained by calcein. Solubilised collagen I can be mixed with living cells during gelation to implant cells in a fibrillar collagen matrix. The force generation and properties of collagen fibrils are comparable to biological filaments, such as actin or microtubules [57]. Non-covalent inter-fibril network interconnections have been reported to transmit cellular traction forces [58]. This may have given rise to extracellular cues that affected cell fate in samples ejected within collagen and bECM relative to hMSCs ejected within PBS. Co-delivery of the cells within the biomaterials studied showed that cells remained viable in vitro 10 days post ejection.

Cell dose recovery did not correlate with the biochemical nature of the polymer (protein-based versus polysaccharide-based), so rheological studies were carried out to investigate possible correlation of cell recovery with mechanical properties of the biomaterials. Shear-thinning behaviour of these biomaterials, showing a relatively large change in the viscosity $\left(\Delta \eta \sim 10^{2}-10^{4}\right.$ Pa.s $)$ from low $\left(0.01 \mathrm{~s}^{-1}\right)$ to high $\left(1000 \mathrm{~s}^{-1}\right)$ shear rates, is a beneficial property for injection-based delivery through narrow-bore needles. Viscometric thixotropy testing revealed that biomaterials were able to recover after shearing, with some biomaterials (collagen and $\mathrm{CMC}$ ) exhibiting more complete recovery than others. Oscillatory shear rheology of the biomaterials also showed that some of the softer materials with lower storage moduli $\left(G^{\prime}\right)$, such as $C M C$ and gelatin, resulted in better cell recovery than collagen, which has a storage modulus that is 10 -fold higher. However, rheological data were not sufficient to explain the significant improvement of cell recovery with gelatin and CMC carriers relative to collagen and bECM. Gelatin and $0.25 \% \mathrm{CMC}$, for example, displayed similar storage moduli (Additional file 4: Figure S4), yet showed significantly different cell dose recovery rates. In addition, viscosities and shear-thinning profiles of the two concentrations of CMC 
under investigation ( 0.5 and $0.25 \%)$ were not significantly different, thereby not explaining the significant difference in dose recovery between them. Therefore, focusing on the rheological properties of a carrier to determine its efficacy at delivering the required number of viable cells is not sufficient.

Surface wettability can influence protein adsorption and, in turn, initial cell attachment. Gelatin resulted in high contact angles on glass despite being structurally similar to collagen due to the preferred orientation of hydrophobic moieties at the air-gel interface, causing a specific arrangement of water molecules [59]. Cell adhesion is similar to physical adhesion in that the cell membrane must make close molecular contact with the surface [60], and therefore we hypothesised that greater levels of cell attachment occurred with surfaces of high wettability since cells can make close contact with these surfaces. Some studies have shown that hydrophilic surfaces produced a significant increase in the amount of protein adsorption, a high initial rate of cell attachment $[61,62]$ and generally better cell adhesion [63]. It has also been reported that cells adhered and proliferated more on surfaces with moderate hydrophilicity than on the more hydrophobic or hydrophilic spots [64]. Improvement of cell attachment with decreasing contact angles has been observed at incubation times of up to $60 \mathrm{~min}$ [62]. The cell carriers with the lowest glass surface wettability in this study displayed the best cell dose recovery. This may be due to the lower contact that these carriers provide with the glass surface of the syringe, discouraging adhesion during the time spent in the delivery device.

Cell recovery trends appeared to correlate with the contact angles displayed by the various carriers, whereby materials displaying the highest contact angles also displayed the highest percentage of cell dose recovered (Figs. 2a and 4b). Moreover, cell recovery did not appear to correlate with the shear-thinning properties of the biomaterials under investigation, as suggested by previous studies $[10,55]$. Collagen, for example, showed the best shear-thinning properties yet the lowest percentage of cell dose recovery between the biomaterials tested. The ability of cells to attach to a surface will depend on the cell type and surface used. Further experiments comparing the attachment of different cell types, syringe material surfaces and a wider range of surface wettability values are required to determine the generality of this observation and make use of it to design more efficient cell delivery systems.

A cell's fate is tightly regulated by its microenvironment, since cells commit to their fate by deriving information from their surroundings [65]. ECM proteins are recognised by cell surface receptors and are involved in cell processes such as proliferation and differentiation. For example, hyaluronan (HA), a naturally occurring polysaccharide found in the ECM of the central nervous system (CNS), can interact with various HA receptors present on diverse cell types to promote cell adhesion and survival [66]. Therefore, it was hypothesised that biomimetic protein-based cell carriers may have a discernible impact on cell commitment and differentiation capacity. Late-stage osteogenic differentiation was enhanced by the protein-based cell carriers, namely collagen, bECM and gelatin, as demonstrated by the mineralisation results. The higher mineralisation levels in samples ejected within collagen $(p<0.01)$ compared to control samples at day 21 suggested that the use of a biomimetic cell carrier for the desired cell type can enhance differentiation response significantly. Fibrilforming collagen type I forms more than $90 \%$ of the organic mass of bone [67]. Bone marrow MSCs have been reported to undergo osteogenesis when cultured on collagen I matrices in vitro by interaction with the COL-I-binding integrin $\alpha 2 \beta 1$ [68]. One study hypothesised that adhesion to ECM proteins, in the absence of soluble osteogenic stimulants, can act as insoluble cues of osteogenesis [69]. Given the tissue specificity of ECM and the abundant presence of collagen in bone-derived ECM [70], these protein-based biomaterials have the potential of mimicking native bone microenvironment pre injection and closely mirror the target site once injected [71]. Since a bipotential differentiation environment was used in this study, it could be hypothesised that overall mineralisation was enhanced due to a higher number of cells being directed towards an osteogenic lineage, such as in ECM (high total mineralisation but similar normalised mineralisation levels per cell), and on a 'mineralisation per cell' basis in the case of PBS (low total mineralisation but trending towards higher normalised mineralisation levels relative to control). There was no significant difference in hydroxyapatite deposition between directly plated and ejected cells within collagen and $\mathrm{bECM}$ at day 21 , suggesting that the more extensive mineralisation observed with these carriers relative to PBS is not augmented by mechanical forces encountered by the cells during ejection.

ALP is widely used as an indicator of osteogenic commitment, and commonly precedes bone matrix mineralisation [72, 73]. Significantly higher levels of ALP released into the media were observed in the unprotected samples ejected within PBS relative to directly plated ones. There was also a notable trend of increased media ALP levels in ejected samples relative to directly plated ones within the same bECM carrier. A similar result was previously obtained by Yourek et al. [74], whereby 24-h exposure to shear stress resulted in higher ALP activity in the media than in control cells. Results of cellular ALP analysis may be due to mechanical forces caused by the ejection process, resulting in the slower 
commitment of ejected cells towards the osteogenic lineage in vitro (in comparison to direct plating), but stronger osteogenic expression. This is implied by later peaking of normalised ALP expression in ejected samples at day 7 , and enhanced mineralisation results with cells ejected within protein-based carriers at day 21 . Results suggest that although shear stress in combination with collagen-based carriers supported osteogenic differentiation more effectively relative to the plated control, the commitment process took longer. Correspondingly, Grellier et al. [75] exposed hMSCs to short periods of fluid shear stress and showed that 30-min exposure upregulated ALP mRNA but 90-min exposure decreased it to almost basal levels. Moreover, MSCs exposed to oscillatory fluid flow displayed reduced ALP activity despite upregulating OCN mRNA under the same conditions [76]. Osteogenic differentiation is complex and multifactorial, and the detailed mechanism of how ALP acts is unclear [77]. Further studies are needed to explore the impact on differentiation in more detail, since it is reasonable to believe that injectable delivery may impair cells' ability to differentiate into the required cell type, or cause differentiation into other undesirable cell types.

\section{Conclusions}

This study demonstrated that the use of natural, lowviscosity biomaterials as cell carriers is an efficient approach to significantly improve the percentage of the cell dose delivered relative to the commonly used saline cell vehicle, enabling the administration of low-dosage cell therapies through narrow, clinically relevant needles. This improvement in cell dose recovery was not associated with the rheological properties of the biomaterials utilised, as had been suggested by previous studies.

Moreover, the extent of differentiation in hMSCs, as demonstrated through the use of osteogenesis as a model of stem cell differentiation, was shown to be substantially altered by the selection of biomaterial carrier, despite limited contact time of the carrier with ejected cells during delivery, as well as ejection rate. The development of tailored biomaterial-assisted cell delivery systems for the desired application will accelerate clinical translation of cell-based therapeutics and allow the utilisation of biomaterials for more efficient cell delivery and potentially directing stem cell fate.

\section{Additional files}

Additional file 1: Figure S1. Showing schematic presentation of methodology used to explore effects of various cell carriers on hMSC delivery. Efficacy of delivery, in terms of cell recovery, viability and proliferation capacity, was assessed. In addition, various parameters of osteogenic differentiation were measured to determine the potential impact of various cell carriers on osteogenic differentiation capacity. (PDF $160 \mathrm{~kb})$
Additional file 2: Figure S2. Showing effect of initial cell seeding density of hMSCs on their osteogenic differentiation potential when cultured in bipotential adipogenic/osteogenic media, quantified based on mineral deposition. (A) Osteolmage ${ }^{\mathrm{TM}}$ staining for hydroxyapatite in hMSCs from two donors seeded at different initial seeding densities in a 12-well plate, cultured in bipotential media for 21 days (mean \pm SD; $n=6$ ). No significant difference revealed between various initial cell seeding densities, analysed using one-way ANOVA and Tukey's post-hoc test. ns no significant difference. (B) Osteolmage ${ }^{T M}$ fluorescence readings normalised to cell count, based on nuclear staining using PI (mean \pm SD, $n=4$ ). Statistical analysis performed using Kruskal-Wallis test with Dunn's post-hoc test. (C) PI cell counts normalised to respective initial cell numbers seeded, expressed as fold change relative to initial cell seeding density (mean $\pm \mathrm{SD}, n=4$ ). Data represent averages from two donors. Statistically significant difference from full seeding density of 70,000 cells/ well: ${ }^{*} p<0.05$, Kruskal-Wallis test with Dunn's post-hoc test. (D) Representative fluorescence microscopy images of hMSCs at day 21. Nuclei stained with Pl, and hydroxyapatite stained fluorescently using Osteolmage ${ }^{\mathrm{TM}}$ (scale bar $=100 \mu \mathrm{m})$. (PDF $1007 \mathrm{~kb}$ )

Additional file 3: Figure S3. Showing effect of initial cell seeding density of hMSCS on their adipogenic differentiation when cultured in bipotential adipogenic/osteogenic media. (A) AdipoRed ${ }^{T M}$ staining for lipid content in hMSCs seeded at different initial seeding densities in a 12-well plate, cultured in bipotential media for 21 days $(n=4)$. Statistically significant difference from the full seeding density of 70,000 cells/well: ${ }^{* *} p<0.01,{ }^{*} p<0.05$, Kruskal-Wallis test with Dunn's post-hoc test. (B) AdipoRed ${ }^{\text {TM }}$ fluorescence readings, adjusted for cellular count based on nuclear staining using Hoechst 33,258 (mean \pm SD, $n=3$ in triplicates). Statistical analysis performed using Kruskal-Wallis test with Dunn's post-hoc test. ${ }^{*} p<0.05$. (C) Fluorescence microscopy images of hMSCs cultured in bipotential differentiation media at day 21. Lipid droplets stained fluorescently using AdipoRed ${ }^{\mathrm{TM}}$ Adipogenesis Reagent, after which nuclei were counterstained with Hoechst (scale bar $=100 \mu \mathrm{m}$ ). (PDF $610 \mathrm{~kb}$ )

Additional file 4: Figure S4. Showing oscillatory rheological measurements of biomaterial-based carriers to obtain storage $\left(G^{\prime}\right)$ and loss (G") moduli from a strain-amplitude sweep (0.1-1000\%) performed at $6 \mathrm{rad} / \mathrm{s}(n \geq 3)$. Carried out for (A) $5(0.5 \%)$ and $2.5(0.25 \%) \mathrm{mg} / \mathrm{ml} \mathrm{CMC}$ (B) $20 \mathrm{mg} / \mathrm{ml}$ (2\%) gelatin, (C) $1.75 \mathrm{mg} / \mathrm{ml}$ collagen and (D) $1.75 \mathrm{mg} / \mathrm{ml}$ bone ECM. (PDF $153 \mathrm{~kb})$

Additional file 5: Figure S5. Showing cellular ALP activity levels of hMSCs at different time points following ejection at $10 \mu \mathrm{l} / \mathrm{min}$ via $30 \mathrm{G}$ needles, and cultured in bipotential media. (A) Cellular ALP analysed 2, 4 and 7 days post induction. Values are mean $\pm \mathrm{SD}$ ( $n=3$ in two donors). Statistically significant differences in ALP levels relative to control (Friedman test with Dunn's post-hoc test: ${ }^{*} p<0.05$. (B) Cellular ALP values normalised to DNA content (mean $\pm \mathrm{SD}, n=3$ in two donors). (C) Normalised cellular ALP levels in ejected versus directly plated hMSCs suspended within collagen and ECM. 'Ejected' cells ejected at $10 \mu \mathrm{l} / \mathrm{min}$, and 'plated' cells were $60 \%$ of the initial cell number directly plated (mean \pm SD, $n=3$ in two donors). (D) DNA content of hMSCs in ejected versus directly plated samples suspended within collagen and ECM (mean \pm SD). (E) Representative immunofluorescent staining of human osteocalcin (OCN) and nuclei counterstained with DAPI (blue) to confirm osteogenic differentiation of hMSCs. Directly plated and ejected hMSCS (via $30 \mathrm{G}$ needles at $10 \mu \mathrm{l} / \mathrm{min}$ ) cultured in bipotential media at 21 days post induction (scale bar $=50 \mu \mathrm{m}$ ). (PDF $926 \mathrm{~kb}$ )

\section{Abbreviations}

ALP: Alkaline phosphatase; bECM: Bone extracellular matrix; hMSC: Human mesenchymal stem cell; OCN: Osteocalcin; PBS: Phosphate buffered saline

\section{Acknowledgements}

The authors are grateful to Dr. Noura Alom for assistance with bECM digests.

Funding

This work was supported by the Biotechnology and Biological Sciences Research Council; the Engineering and Physical Sciences Research Council; and the Medical Research Council [grant number MR/K026682/1] via the UK 
Regenerative Medicine Platform Hubs 'Acellular Approaches for Therapeutic Delivery'. MHA was funded by a University of Nottingham International Office scholarship and the 'Faculty for the Future' program of the Schlumberger Foundation.

\section{Availability of data and materials}

The datasets used and/or analysed during the current study are available from the corresponding author on reasonable request.

\section{Authors' contributions}

All authors read and approved the final manuscript. MHA contributed to design, collection and assembly of data, data analysis and interpretation, and manuscript writing. FRAJR and LJW contributed to revision and final approval of the manuscript. KMS contributed to conception, financial support and revision and final approval of the manuscript.

\section{Ethics approval and consent to participate} Not applicable.

\section{Consent for publication}

Not applicable.

\section{Competing interests}

The authors declare that they have no competing interests.

\section{Publisher's Note}

Springer Nature remains neutral with regard to jurisdictional claims in published maps and institutional affiliations.

Received: 4 December 2017 Revised: 16 January 2018 Accepted: 23 January 2018 Published online: 21 February 2018

\section{References}

1. Mackay-Sim A, Feron F, Cochrane J, Bassingthwaighte L, Bayliss C, Davies W, Fronek P, Gray C, Kerr G, Licina P, et al. Autologous olfactory ensheathing cell transplantation in human paraplegia: a 3-year clinical trial. Brain. 2008; 131:2376-86.

2. Rossetti T, Nicholls F, Modo M. Intracerebral cell implantation: preparation and characterization of cell suspensions. Cell Transplant. 2016;25:645-64.

3. Kalladka D, Sinden J, Pollock K, Haig C, McLean J, Smith W, McConnachie A, Santosh C, Bath PM, Dunn L, Muir KW. Human neural stem cells in patients with chronic ischaemic stroke (PISCES): a phase 1, first-in-man study. Lancet. 2016;388:787-96.

4. Teng CJ, Luo J, Chiu RC, Shum-Tim D. Massive mechanical loss of microspheres with direct intramyocardial injection in the beating heart: implications for cellular cardiomyoplasty. J Thorac Cardiovasc Surg. 2006; 132:628-32.

5. Mooney DJ, Vandenburgh H. Cell delivery mechanisms for tissue repair. Cell Stem Cell. 2008;2:205-13.

6. Lin SZ. Translational cell therapies in regenerative medicine and cancers. Cell Transplant. 2016;25:781-2.

7. Watt FM, Hogan BLM. Out of Eden: stem cells and their niches. Science. 2000;287:1427-30

8. Huebsch N, Lippens E, Lee K, Mehta M, Koshy ST, Darnell MC, Desai RM, Madl CM, Xu M, Zhao X, et al. Matrix elasticity of void-forming hydrogels controls transplanted-stem-cell-mediated bone formation. Nat Mater. 2015; 14:1269-77.

9. Lutolf MP. Integration column: artificial ECM: expanding the cell biology toolbox in 3D. Integr Biol (Camb). 2009:1:235-41.

10. Aguado BA, Mulyasasmita W, Su J, Lampe KJ, Heilshorn SC. Improving viability of stem cells during syringe needle flow through the design of hydrogel cell carriers. Tissue Eng Part A. 2012;18:806-15.

11. Potier E, Noailly J, Ito K. Directing bone marrow-derived stromal cell function with mechanics. J Biomech. 2010;43:807-17.

12. Estes BT, Gimble JM, Guilak F. Mechanical signals as regulators of stem cell fate. Curr Top Dev Biol. 2004:60:91-126.

13. Sun Y, Chen CS, Fu J. Forcing stem cells to behave: a biophysical perspective of the cellular microenvironment. Annu Rev Biophys. 2012:41: 519-42.

14. Engler AJ, Sen S, Sweeney HL, Discher DE. Matrix elasticity directs stem cell lineage specification. Cell. 2006;126:677-89.
15. Higuchi A, Ling QD, Chang Y, Hsu ST, Umezawa A. Physical cues of biomaterials guide stem cell differentiation fate. Chem Rev. 2013;113:3297328.

16. Kearney CJ, Mooney DJ. Macroscale delivery systems for molecular and cellular payloads. Nat Mater. 2013;12:1004-17.

17. Boccafoschi F, Habermehl J, Vesentini S, Mantovani D. Biological performances of collagen-based scaffolds for vascular tissue engineering. Biomaterials. 2005;26:7410-7.

18. Gonen-Wadmany M, Gepstein L, Seliktar D. Controlling the cellular organization of tissue-engineered cardiac constructs. Ann N Y Acad Sci. 2004;1015:299-311.

19. Gingras M, Beaulieu MM, Gagnon V, Durham HD, Berthod F. In vitro study of axonal migration and myelination of motor neurons in a threedimensional tissue-engineered model. Glia. 2008;56:354-64.

20. Dewitt DD, Kaszuba SN, Thompson DM, Stegemann JP. Collagen I-matrigel scaffolds for enhanced Schwann cell survival and control of threedimensional cell morphology. Tissue Eng Part A. 2009;15:2785-93.

21. Phillips JB, Brown R. Micro-structured materials and mechanical cues in 3D collagen gels. Methods Mol Biol. 2011:695:183-96.

22. Badylak SF, Freytes DO, Gilbert TW. Extracellular matrix as a biological scaffold material: structure and function. Acta Biomater. 2009:5:1-13.

23. Saldin LT, Cramer MC, Velankar SS, White LJ, Badylak SF. Extracellular matrix hydrogels from decellularized tissues: structure and function. Acta Biomater. 2017:49:1-15.

24. Malafaya PB, Silva GA, Reis RL. Natural-origin polymers as carriers and scaffolds for biomolecules and cell delivery in tissue engineering applications. Adv Drug Deliv Rev. 2007;59:207-33.

25. Miyamoto T, Takahashi S, Ito H, Inagaki H, Noishiki Y. Tissue biocompatibility of cellulose and its derivatives. J Biomed Mater Res. 1989;23:125-33.

26. Tharanathan RN. Biodegradable films and composite coatings: past, present and future. Trends Food Sci Technol. 2003;14:71-8.

27. Chen Q, Shou P, Zheng C, Jiang M, Cao G, Yang Q, Cao J, Xie N, Velletri T, Zhang $X$, et al. Fate decision of mesenchymal stem cells: adipocytes or osteoblasts? Cell Death Differ. 2016;23:1128-39.

28. Amer MH, Rose FR, White LJ, Shakesheff KM. A detailed assessment of varying ejection rate on delivery efficiency of mesenchymal stem cells using narrow-bore needles. Stem Cells Transl Med. 2016;5(3):366-78.

29. Amer MH, White $L$, Shakesheff KM. The effect of injection using narrowbore needles on mammalian cells: administration and formulation considerations for cell therapies. J Pharm Pharmacol. 2015:67:640-50.

30. Dominici M, Le Blanc K, Mueller I, Slaper-Cortenbach I, Marini F, Krause D, Deans R, Keating A, Prockop D, Horwitz E. Minimal criteria for defining multipotent mesenchymal stromal cells. The International Society for Cellular Therapy position statement. Cytotherapy. 2006;8:315-7.

31. Qiao LY, Huang FJ, Zhao M, Xie JH, Shi J, Wang J, Lin XZ, Zuo H, Wang YL, Geng TC. A two-year follow-up study of cotransplantation with neural stem/ progenitor cells and mesenchymal stromal cells in ischemic stroke patients. Cell Transplant. 2014;23(Suppl 1):S65-72.

32. Moriya K, Yoshikawa M, Ouji Y, Saito K, Nishiofuku M, Matsuda R, Ishizaka S, Fukui $\mathrm{H}$. Embryonic stem cells reduce liver fibrosis in CCl4-treated mice. Int J Exp Pathol. 2008;89:401-9.

33. Salama H, Zekri AR, Medhat E, Al Alim SA, Ahmed OS, Bahnassy AA, Lotfy MM, Ahmed R, Musa S. Peripheral vein infusion of autologous mesenchymal stem cells in Egyptian HCV-positive patients with end-stage liver disease. Stem Cell Res Ther. 2014:5:70.

34. Torres EM, Trigano M, Dunnett SB. Translation of cell therapies to the clinic: characteristics of cell suspensions in large-diameter injection cannulae. Cell Transplant. 2015;24:737-49.

35. Glass JD, Boulis NM, Johe K, Rutkove SB, Federici T, Polak M, Kelly C, Feldman EL. Lumbar intraspinal injection of neural stem cells in patients with amyotrophic lateral sclerosis: results of a phase I trial in 12 patients. Stem Cells. 2012:30:1144-51.

36. Misra V, Lal A, El Khoury R, Chen PR, Savitz SI. Intra-arterial delivery of cell therapies for stroke. Stem Cells Dev. 2012;21:1007-15.

37. Rosado-de-Castro PH, Pimentel-Coelho PM, da Fonseca LM, de Freitas GR, Mendez-Otero R. The rise of cell therapy trials for stroke: review of published and registered studies. Stem Cells Dev. 2013;22:2095-111.

38. Sawkins MJ, Bowen W, Dhadda P, Markides H, Sidney LE, Taylor AJ, Rose FR, Badylak SF, Shakesheff KM, White LJ. Hydrogels derived from demineralized and decellularized bone extracellular matrix. Acta Biomater. 2013;9:7865-73.

39. Wu S. Polymer interface and adhesion. Textile Res J. 1983;53:452. 
40. Grayson WL, Bhumiratana S, Cannizzaro C, Chao PH, Lennon DP, Caplan Al Vunjak-Novakovic G. Effects of initial seeding density and fluid perfusion rate on formation of tissue-engineered bone. Tissue Eng Part A. 2008;14: 1809-20.

41. Shearn J, Hellmann L, Boivin G. Effect of initial cell-seeding density on postoperative cell number and dispersion. Tissue Eng. 2005;11:1898-904

42. Holy CE, Shoichet MS, Davies JE. Engineering three-dimensional bone tissue in vitro using biodegradable scaffolds: investigating initial cell-seeding density and culture period. J Biomed Mater Res. 2000;51:376-82.

43. McBeath R, Pirone DM, Nelson CM, Bhadriraju K, Chen CS. Cell shape, cytoskeletal tension, and RhoA regulate stem cell lineage commitment. Dev Cell. 2004;6:483-95.

44. Ni XF, Crozatier C, Sensebe L, Langonne A, Wang L, Fan Y, He PG, Chen Y. On-chip differentiation of human mesenchymal stem cells into adipocytes. Microelectron Eng. 2008;85:1330-3.

45. Hoemann CD, El-Gabalawy H, Mckee MD. In vitro osteogenesis assays: influence of the primary cell source on alkaline phosphatase activity and mineralization. Pathol Biol. 2009;57:318-23.

46. Kreke MR, Goldstein AS. Hydrodynamic shear stimulates osteocalcin expression but not proliferation of bone marrow stromal cells. Tissue Eng. 2004;10:780-8.

47. Holtorf $\mathrm{HL}$, Jansen JA, Mikos AG. Flow perfusion culture induces the osteoblastic differentiation of marrow stroma cell-scaffold constructs in the absence of dexamethasone. J Biomed Mater Res A. 2005;72:326-34.

48. Bancroft GN, Sikavitsas VI, van den Dolder J, Sheffield TL, Ambrose CG, Jansen JA, Mikos AG. Fluid flow increases mineralized matrix deposition in $3 \mathrm{D}$ perfusion culture of marrow stromal osteoblasts in a dose-dependent manner. Proc Natl Acad Sci U S A. 2002;99:12600-5.

49. Frantz C, Stewart KM, Weaver VM. The extracellular matrix at a glance. J Cell Sci. 2010;123:4195-200

50. Lu D, Mahmood A, Qu C, Hong X, Kaplan D, Chopp M. Collagen scaffolds populated with human marrow stromal cells reduce lesion volume and improve functional outcome after traumatic brain injury. Neurosurgery. 2007;61:596-602. discussion 602-3

51. Xiong Y, Qu C, Mahmood A, Liu Z, Ning R, Li Y, Kaplan DL, Schallert T, Chopp M. Delayed transplantation of human marrow stromal cell-seeded scaffolds increases transcallosal neural fiber length, angiogenesis, and hippocampal neuronal survival and improves functional outcome after traumatic brain injury in rats. Brain Res. 2009;1263:183-91.

52. Di Lullo GA, Sweeney SM, Korkko J, Ala-Kokko L, San Antonio JD. Mapping the ligand-binding sites and disease-associated mutations on the most abundant protein in the human, type I collagen. J Biol Chem. 2002;277: 4223-31.

53. Van Nieuwenhove I, Salamon A, Adam S, Dubruel P, Van Vlierberghe S, Peters K. Gelatin- and starch-based hydrogels. Part B: in vitro mesenchymal stem cell behavior on the hydrogels. Carbohydr Polym. 2017;161:295-305.

54. Camacho FG, Grima EM, Miron AS, Pascual VG, Chisti Y. Carboxymethyl cellulose protects algal cells against hydrodynamic stress. Enzym Microb Technol. 2001;29:602-10.

55. Yan C, Altunbas A, Yucel T, Nagarkar RP, Schneider JP, Pochan DJ. Injectable solid hydrogel: mechanism of shear-thinning and immediate recovery of injectable beta-hairpin peptide hydrogels. Soft Matter. 2010;6:5143-56.

56. Jolkkonen J, Walczak P. Clinical Trials: Intracerebral cell therapy in stroke patients. In Cell-based therapies in stroke. Springer-Verlag Wien: Springer Science \& Business Media; 2013.

57. Shayegan M, Forde NR. Microrheological characterization of collagen systems: from molecular solutions to fibrillar gels. PLoS One. 2013;8:e70590.

58. Grinnell F, Lamke CR. Reorganization of hydrated collagen lattices by human skin fibroblasts. J Cell Sci. 1984;66:51-63.

59. Bialopiotrowicz T, Janczuk B. Surface properties of gelatin films. Langmuir. 2002;18:9462-8.

60. Grinnell F, Milam M, Srere PA. Atachment of normal and transformed hamster kidney cells to substrata varying in chemical composition. Biochem Med. 1973;7:87-90.

61. Hao L, Lawrence J. Albumin and fibronectin protein adsorption on CO2-lasermodified biograde stainless steel. Proc Inst Mech Eng H. 2006;220:47-55.

62. Wei J, Igarashi T, Okumori N, Igarashi T, Maetani T, Liu B, Yoshinari M. Influence of surface wettability on competitive protein adsorption and initial attachment of osteoblasts. Biomed Mater. 2009;4:045002.
63. Altankov G, Groth T. Reorganization of substratum-bound fibronectin on hydrophilic and hydrophobic materials is related to biocompatibility. J Mater Sci Mat Med. 1994;5:732-7.

64. Lee JH, Khang G, Lee JW, Lee HB. Interaction of different types of cells on polymer surfaces with wettability gradient. J Colloid Interface Sci. 1998;205: 323-30.

65. Murry CE, Keller G. Differentiation of embryonic stem cells to clinically relevant populations: lessons from embryonic development. Cell. 2008;132: 661-80.

66. Jiang D, Liang J, Noble PW. Hyaluronan in tissue injury and repair. Annu Rev Cell Dev Biol. 2007;23:435-61.

67. Gelse K, Poschl E, Aigner T. Collagens —-structure, function, and biosynthesis. Adv Drug Deliv Rev. 2003:55:1531-46.

68. Mizuno M, Kuboki Y. Osteoblast-related gene expression of bone marrow cells during the osteoblastic differentiation induced by type I collagen. J Biochem. 2001;129:133-8.

69. Salasznyk RM, Williams WA, Boskey A, Batorsky A, Plopper GE. Adhesion to vitronectin and collagen I promotes osteogenic differentiation of human mesenchymal stem cells. J Biomed Biotechnol. 2004;2004:24-34.

70. Viswanath A, Vanacker J, Germain L, Leprince JG, Diogenes A, Shakesheff K, White $L J$, des Rieux A. Extracellular matrix-derived hydrogels for dental stem cell delivery. J Biomed Mater Res A. 2017:105A:319-28.

71. Seif-Naraghi SB, Singelyn JM, Salvatore MA, Osborn KG, Wang JJ, Sampat U, Kwan OL, Strachan GM, Wong J, Schup-Magoffin PJ, et al. Safety and efficacy of an injectable extracellular matrix hydrogel for treating myocardial infarction. Sci Transl Med. 2013;5:173ra125.

72. Faia-Torres AB, Guimond-Lischer S, Rottmar M, Charnley M, Goren T, Maniura-Weber K, Spencer ND, Reis RL, Textor M, Neves NM. Differential regulation of osteogenic differentiation of stem cells on surface roughness gradients. Biomaterials. 2014;35:9023-32.

73. Prins HJ, Braat AK, Gawlitta D, Dhert WJ, Egan DA, Tijssen-Slump E, Yuan H, Coffer PJ, Rozemuller H, Martens AC. In vitro induction of alkaline phosphatase levels predicts in vivo bone forming capacity of human bone marrow stromal cells. Stem Cell Res. 2014;12:428-40.

74. Yourek G, McCormick SM, Mao JJ, Reilly GC. Shear stress induces osteogenic differentiation of human mesenchymal stem cells. Regen Med. 2010;5:713-24.

75. Grellier M, Bareille R, Bourget C, Amedee J. Responsiveness of human bone marrow stromal cells to shear stress. J Tissue Eng Regen Med. 2009;3:302-9.

76. Li YJ, Batra NN, You L, Meier SC, Coe IA, Yellowley CE, Jacobs CR. Oscillatory fluid flow affects human marrow stromal cell proliferation and differentiation. J Orthop Res. 2004;22:1283-9.

77. Golub EE, Harrison G, Taylor AG, Camper S, Shapiro IM. The role of alkaline phosphatase in cartilage mineralization. Bone Miner. 1992;17:273-8.

\section{Submit your next manuscript to BioMed Central and we will help you at every step:}

- We accept pre-submission inquiries

- Our selector tool helps you to find the most relevant journal

- We provide round the clock customer support

- Convenient online submission

- Thorough peer review

- Inclusion in PubMed and all major indexing services

- Maximum visibility for your research

Submit your manuscript at www.biomedcentral.com/submit 